\title{
DINING ON RECIPROCITY IN LOCAL FOOD SYSTEMS: TOWARDS A MORAL ECONOMY OF FOODS
}

\author{
Li Zhao \\ Rural Development Institute, Chinese Academy of Social Sciences No. 5 Jianguomennei \\ Avenue, Dongcheng District 100732, Beijing, China. \\ E-mail: zhao-li@,cass.org.cn
}

Citation: Zhao, L. 2018. Dining on Reciprocity in Local Food Systems: Towards A Moral Economy of Foods. J. Asian Rur. Stud. 2(1): 85-95

\begin{abstract}
China has witnessed a growing number of social and environmental challenges, which remain obstacles for its rural vitalization. At the core of the discussion on sustainable agriculture and rural development lies the development of sustainable food systems. This article conducts a case study and examines a local food network which has created a reciprocity mechanism between smallholder producers and consumers. The discussion puts a particular emphasis on the interaction between sustainable consumption and production initiatives in the process of achieving the network's ecological goals. Based on the discussion and findings, the study concludes by proposing to draw on the concept of the moral economy and constructing "a moral economy of foods" to conceptualize social structure of local food systems. In a relocalization process of "local cultural repertoires of foods", while protocols of certification and traceability could constitute conclusive proofs of the moral economy of foods, a belief in sustainable food systems would stand the moral economy itself in good stead in a time when trust and confidence in the foods labeled "organic" are diminished. The findings presented in the study may have significant implications for designing policies for rural vitalization in China and promoting transitions to more sustainable agriculture and rural livelihoods.
\end{abstract}

Keywords: Local food system; alternative food network; sustainable consumption; sustainable production; moral economy of foods

\section{Introduction}

In the last decades, the macro-economic development in China has led to massive processes of industrialization and urbanization. Meanwhile, China's agriculture and rural society have undergone rapid changes. In the midst of transition processes, social and environmental challenges have been increasingly witnessed and well-recognized, including agriculture's ecological sustainability crisis, pollution of air, soil and water, food safety as well as dissolution of rural communities. From the institutional perspective, many government policies and programs are being implemented to address them, for instance, the recently issued National Plan for Sustainable Development of Agriculture (2015-2030). The government is also expanding specific forms of sustainable agriculture, including ecological and circular agriculture models, and organic agriculture. Recently, a sustainable rural development has been highly addressed in order to realize a rural vitalization strategy as proposed by General Secretary Xi Jinping in his report to the $19^{\text {th }}$ National Congress of the Communist Party 
of China held in October, 2017. The rural vitalization strategy represents China's core idea and key pathway for a sustainable rural development. This is the first time that this strategy has been featured in a Central Committee's document.

At the core of the discussion on sustainable agriculture and rural development lies the development of sustainable food systems. According to Chinese scholars, there are two main discourses in food systems research and practices: conventional food networks and alternative food networks. It is widely agreed that the former has a number of negative impacts on economic, social and environmental aspects. In China, a majority of farmers are being involved in commercial entrepreneurship and conventional agriculture in which a focus on commercial success and an increase in shareholders' wealth are placed at the central place, rather than cultivation of local food production and consumption systems, social equity, environmental and ecological sustainability and sustainable community development.

Meanwhile, there are a great number of smallholders who are scattered all over the country, not yet being completely wiped out by commercialized, modernized agriculture. They are still farming in an indigenous way, working hard and preserving traditional crop varieties. These individual farmers are still struggling to find a way to stand in the food systems, reach consumers and gain their trust. Alternative food networks are regarded as new food networks that have the potential to overcome the drawbacks that conventional food networks have. Worldwide, they refer to a heterogeneous group of initiatives and diverse practices such as the organic movement, fair trade projects, community-supported agriculture (CSA), community gardens, slow food and farmers' markets (King, 2008; Roos et al., 2007; Si et al., 2015). Goodman et al. (2012) consider alternative food networks as "new economic and cultural spaces for the trading, production, and consumption of food". The common characteristics shared by these initiatives are their objectives to redistribute value through the networks against the logic of bulk commodity production, their critique of conventional models of production and consumption, their efforts to build trust between food producers and consumers, and their willingness to articulate new forms of market governance and democratic association (Whatmore et al., 2003).

This article puts a particular emphasis on the interaction and link between sustainable consumption and production initiatives in achieving ecological goals in a local food network. More specifically, it discusses how a responsible dining behavior is built on reciprocity mechanisms between producers and consumers, how sustainability agriculture can be promoted, and how social equity can be enhanced through a pilot project initiative in China. It is organized as follows. The next section provides a brief literature review on the challenges of modern food systems in the age of globalization. After a short description of the methodology part, it then presents a case study of a local food network, an initiative involving the characteristics of community-supported agriculture and fair trade movement. In the fifth section, it concludes by exploring the potentials that local food networks may have in supporting farmers both economically and socially, which enables the development of a moral economy of foods. The support provided by the local food system, as we believe, may be especially important in China, where consumers seem increasingly likely to recognize that quality of life means more than just wealth, abundance and material comfort. This has further influenced their 
consumption attitudes and behaviors, their consciousness about health benefits and well-beings and their expectations about foods.

Challenges of Modern Food Systems

The paradigm shift from traditional to modern food systems has been described extensively in the literature. Along with the process of agricultural industrialization, the development of modern global food systems has moved away from the principles of sustainability (e.g. O'Kane, 2012; Schlosser, 2001). Scholars have widely noticed that the modern agricultural sector led by global "food empires" (Van der Ploeg, 2010) has caused a wide range of environmental externalities, including conversion of land for agricultural purposes, crop and livestock production, fertilizer application, water and energy use, to name just a few (Chen, 1990). The conventional modern food systems of commercialized global agricultural supply and commodity chains have generated negative impacts on the environment, contributing particularly to unsustainable farming practices and biodiversity disruption and loss.

Unsustainable farming practices, such as the overuse of fertilizers, have posed a critical challenge to a sustainable development of agriculture. In China, in the early 1960s after three years of the Great Famine, more emphasis from the traditional farming was shifted to the use of chemical fertilizers. Three decades after the Chinese government initiated a series of institutional changes and reforms designed to boost efficiency in agricultural production, China has now become the world's leader in both chemical fertilizer and pesticide consumption (FAO, 2006). In the past three decades, consumption of chemical fertilizers has increased sevenfold, from 8.8 million tonnes in 1978 to 59 million in $2013(\mathrm{Ng}, 2015)$. About 30 percent of world's fertilizers are used in rural China, the average rate being more than twice the world average. The excessive use of fertilizers and pesticides has generated considerable environmental pollution, contamination of plants and soils, land degradation and widespread ecological damage. A report published on Nature (Gilbert, 2010) claims that "Chinese farmers' rampant use of fertilizers could soon endanger the nation's ability to feed itself". Consequently, it becomes likely that environmental problems generated from unbalanced agricultural growth would threaten agricultural productivity and impose serious environmental burdens on future generations.

The shift in farming practices as an expression of technological change can be identified as one important factor that contributes to biodiversity loss (Tisdell, 2003, 2011). Biodiversity disruption can bring about tragic consequences. On one hand, loss of biodiversity and natural resources can exacerbate current risks related to poverty (Secretariat of the Convention on Biological Diversity, 2014). When ecosystems are pushed towards critical thresholds, there can be a real risk of biodiversity loss and degradation of a wide scope of services upon which indigenous residents depend for their livelihoods and well-beings. On the other hand, the studies on interdependency between biodiversity and cultural diversity also indicate that the accelerated loss of biodiversity exhibits destruction of the unique relationships between all life forms and human cultures, in addition to a loss of gene, species, and ecosystem (Pei, 2006; Xue et al., 2015). There is a growing belief that a strong tendency towards genetic and ecological uniformity driven by the development of modern agriculture has posed challenges to ecological sustainability (Ezcurra et al., 2001). Along with rapid growth of a market economy, China has witnessed the continuing transformation of natural 
ecosystems. Emphasis on productivity gains and growth associated with modern inputs such as chemical fertilizers, the use of improved seed varieties and distortion of cropping patterns, has caused genetic erosion or a loss of crop genetic resources. Local varieties of domestic crops have been replaced with high-yield varieties, leading to the diminishing of important gene pools, including cultivated and wild varieties. For example, Gao (2003) reports that genetic erosion of cultivated rice and its wild relatives in China has been threatening the integrity of the Chinese rice gene pool.

The development of modern agriculture and food systems has not only caused biodiversity disruption in rural ecosystems, but also affects rural residents. The current global food system operates in favor of large multinational food companies and agribusinesses instead of smallholder farmers (Lawrence and Grice, 2008; O'Kane, 2012). Owing to the monopoly power held by global food empires, many smallholders were integrated into commercialized agricultural supply and commodity chains worldwide, being increasingly dependent on global food supply chain (Van der Ploeg, 2010). The structures of global food empires that link food production and consumption "have a strong inbuilt need to 'squeeze out' as much value as possible, by exerting a permanent downward pressure on the prices received by primary producers and an upward pressure on food prices paid by consumers, allowing for considerable accumulation" (Van der Ploeg, 2010).

In China, as state authorities and capitalist firms have been operating in vast rural areas and transforming rural landscapes and livelihoods, rural people have become increasingly involved in contract farming, factory farms or simply displaced from the land, struggling to make a living in cities. Similar to their counterparts in other countries (Clouse, 1995; Lewontin and Berlan, 1986; Welsh, 1997), contract farmers in China are in a vulnerable position in production contracting, having little control over the production process and farm-gate prices. Decisions over type and quality of inputs, production methods, choice of feeding regime, for example, are moving away from farm-level individual producers towards off-farm processing companies, brokers and retail channels. Meanwhile, similar to a majority of the developed economies where the food processing and retailing sectors have become highly concentrated, an increasing level of concentration in the Chinese food industry can also be witnessed ( $\mathrm{Yu}$ et al., 2016). The shift of decision-making power, together with increasing levels of concentration in the food sector, led Chinese small producers and contract farmers to become more vulnerable in the modern food systems.

Coupled with the shifts in farming practices and food systems, the change in consumption patterns, nutrition transition and consumers' growing awareness of food safety have been discerned. The rapid changes in modern food systems, characterized by increasing consumption of ultra-processed foods distributed particularly through modern grocery retail channels and increasing fast food sales, contribute significantly to ongoing dietary change (Baker and Friel, 2016). Along with these shifts in consumption patterns, consumers have become physically and socially disconnected from the origin of their foods (O'Kane, 2012; Turner and Hope, 2014). Meanwhile, they have become increasingly concerned about nutritional adequacy, health benefits and food safety. These changes have received continued scholarly attention both internationally and in China (FORHEAD, 2014; Garnett and Wilkes, 2014). 


\section{Method}

Confronted with widespread rural environmental pollution and land degeneration which damage agriculture's ecological sustainability, a multitude of activities have been conducted nation-wide in China. Being resistant to chemical agriculture, these activities and initiatives have performed traditional farming methods, integrating the land, plants, animals and using polyculture system mix of various crops. In some regions, local farmers (mostly elders) are well aware of the problems and desire to revive traditional farming, but they lack the necessary confidence and energy. Therefore, at the very beginning, Chinese activists have provided tremendous supports and efforts to advocate for sustainability. They endeavored to persuade local farmers to fully abandon chemical fertilizers, and to convince conscious consumers from cities of reliable source of organic foods, ensuring stable distribution channels and a good price for these laborconsuming products. Some projects started out with urban consumers, while others are promoted by scholars and practitioners with significant support from volunteers and rural farmers.

For this research, the author chooses a pilot project of local food network as a case study. This case can be regarded as one of the most representative and pioneering local food networks in China, being a grassroots initiative originated by a couple of consumers since 2003. The analysis presented in this study is based on the findings of extensive reviews of the English and Chinese language literature. Literature reviews have been gathered in the last ten years, mainly based on peer reviewed journals, media sources, academic reports, peer exchanges and grey literature. Numerous primary and secondary literature sources were relied on to trace the emergence and development of the case. In 2017, the author conducted open-ended in-depth interviews with the initiators. This enabled to triangulate the information that was gathered before and to document recent initiatives and development. Interview transcripts were used to unfold the saga with a view to drawing out implications for a repertoire of alternative food networks in China. In addition, the author observed how the network operated from the participant's perspective.

\section{Results and Discussion}

\section{A Case of Sustainable Food Network}

In the early of 2000s, four resident consumers, dissatisfied with the foods they had while dining out in their city located in the Southern part of China, formed a local value-based supply chain to create a market channel for healthy, tasty foods. They went to the countryside to search for indigenous, local foods and dined with local rural farmers. Two years later, they established a first restaurant in the city to support the survival of local smallholders and to encourage the development of a sustainable agroecosystem in the region. This small value-based supply chain worked in a loose network with dozens of small producers, whose farmland ranged in size from only 0.1 acre to a few acres. In this loose network, oral contracts were made in a rather informal way between the restaurant and small producers. However, growers who participated in this food network were guaranteed with a fair price much higher than what they could otherwise get from local spot markets or conventional food systems dominated by agribusiness firms and supermarket chains. On a small but economically and environmentally significant scale in the region, participant growers of the food network 
have replaced unsustainable crop monoculture with low chemical fertilizers, biologically diverse farming systems based on biological fertilizers, complex crop rotations, ecologically appropriate crops selection and multi-purposed plantations that formed an agro-ecosystem in their local areas. It is worth noting that the initiators of the case network were reluctant to adopt the term "organic", which they regarded as a Western terminology. They rather preferred to use the Chinese word "tu" (土), and regard their project as a way to celebrating rural traditions and protecting health and environment.

Through stimulating the development of traditional farming and the production of indigenous foods, this local value-based supply chain pursued a number of ecological goals. As a first ecological goal, the initiators of this food network, being concerned about food safety, envisaged to increase the scale of farmland in which traditional production methods were applied. Secondly, the case network aimed to engage actively in procuring local, seasonal, fresh, high quality foods and prepared healthy, tasty meals for consumers in cities. Thirdly, it desired to promote indigenous varieties through protecting the cultivation of local seeds and seedlings, as well as traditional craftsmanship. Fourthly, the network under study aimed to promote a more balanced ecosystem based on crop-rotation and mixed farming systems with crops and animals. For the purpose of discussion, this section examines how the case under study attempted to guarantee its goal achievement by way of linking sustainable consumption and production initiatives. Through building direct relationship between growers and consumers, the case network adopted a participatory guarantee system approach to guarantee the genuinity of biological, local foods without getting involved in a "certified" organic market.

\subsection{Sustainable Consumption}

Normally, the cost-price squeeze that in great part happens in contract production of agri-commodities is likely to lead small producers to ignore ecological consequences of their farming practices (Sage, 2012). Impoverished farmers facing a continuing squeeze can hardly afford to provide the care that is required for the production of healthy and high-quality food (Van der Ploeg, 2010). Therefore, in order to achieve its first ecological goal, the case under study needs to encourage the adoption of traditional production methods by providing a fair price to its participant producers. Generally speaking, traditional farming methods require considerably more care and costs than modern production. Prices of products from traditional farming are higher than their counterparts. But how high is high enough? In the case network, the initiators have made a calculation together with the producers, taking into consideration the costs of labor and production risks. For example, to decide the price of yuba or tofu skin in a local region with a long production tradition, the initiators and craftsmen started the discussion by calculating the expected production outputs per craftsman on a normal day, multiplied by the number of working days per month which can differ from month to month. In an artisan way of yuba production, a beneficial weather condition is a prerequisite. Craftsmen can make yuba only on dry, windy days, in which days they need to get up early in the morning to start and stop working at noon when the sunshine becomes bright. In order to render enough support to the artisan craftsmanship of yubamaking in the local region, the food network needed to provide a price at which 
craftsmen could sustain their livelihoods. Currently, this price is about five times as much as that found on Taobao in China. As another example, the initiators of the case determined the prices paid for meat products by taking into consideration the probability of yield drop owing to the fact that animals were fed in the natural manner without being given any antibiotics or hormones.

Despite the high level of consumption prices, a slowly increasing number of consumers have dined out on a regular basis in the restaurant. Therefore, this high price level was determined in a manner by a growing sense of awareness of consumers motivated by economic, social and ecological concerns. This high price has presented their understanding towards sustainable consumption. Most consumers who came for meals were those who seemed to share and understand the alternative values put forward by the network. In fact, a growing body of evidence already demonstrates the role played by local food networks in providing opportunities for customers to reconnect to their food system (Turner and Hope, 2014). Therefore, in the case network, consumption behavior also represents the farming practices that consumers identify to be right and moral, as what has been emphasized by the initiators (interview code T-01 and Z-01).

Like traditional food systems, the case under study is characterized by short supply chains involving production, distribution and consumption of unprocessed or minimally processed foods at a local level. This ensures its second ecological goal in that the restaurant could get daily fresh ingredients, based upon which the chefs could prepare meals for consumers with very limited seasonings. "No chef would prepare a dish without seasoning. The chefs from other restaurants coming here for cooking skill exchanges only found out they can't learn anything from here 'cause what we only use are (biological) oil and salt. By artificial cooking skills and adding seasonings you'd already change the ingredients' original tastes. We however try to present dishes with the original tastes of foods" (interview code T-03). However, for those conventional consumers, "this can't guarantee popularity and success among them 'cause when they dine out, they normally expect some special flavors which they don't get at home" (interview code H-01). A large number of consumers would probably know the negative effects of seasonings' addiction on their health so they tend to add less or no seasonings when they cook at home. According to the case, a conventional consumer would probably concern more about the meal's flavors than a healthy meal while dining out. By making posters with brightly colored slogans and interesting, inspirational quotes and presenting them in the restaurant, the network initiators have made great endeavors to promote in public their alternative values on having healthy, tasty foods and dining on reciprocity. As a renowned anthropologist Margaret Mead said, “...efforts to better the nutrition of the world simply by altered production and distribution will fall short of their goals unless corresponding and congruent changes are made in the patterns of consumption" (Mead, 2008; see Sage, 2012). By way of convincing more consumers of the original tastes of local foods, the network envisaged to render more support for sustainable smallholder production. 


\subsection{Sustainable Production}

According to the initiators of the case under examination, a responsible dining behavior should be based on an understanding and appreciation of local production stories of their foods. In this case, consumption should be understood contextually.

The case network has launched programs to promote indigenous varieties and artisan craftsmanship. But this goal could only be achieved through its encouragement of traditional crop production, which can then stimulate the use and preservation of local plantation varieties due to their better resistance capabilities to illnesses and pests and to their better adjustment to local conditions. The examples of indigenous varieties that were included in the network's promotion programs are local rice and beans, native chicken and black pigs, to name just a few. Meanwhile, a good example for preserving traditional craftsmanship is yuba making skills. "According to the craftsmen, on dry and windy days, even the kids can make it, very easy", "that means, making sheets out of tofu in a traditional way depends mostly on the nature. When addictives adoption becomes popular thanks to the technological advancement, making sheets out of tofu doesn't reply on the weather any more. This is against the nature law" (interview code Z-02). Based on the practices of the case under study, traditional rearing and crafting systems have generated a positive impact on preserving the genetic diversity of crops and animals in the region.

Furthermore, to promote mixed farming systems with the integration of crop and livestock productions, the network under study required its producers who provided meat to the restaurant to have their own piece of land, and to provide meat or crops that were grown solely by themselves. During the time when a yearly production plan is made at the beginning of a year, the producers could decide the volume of produce to be provided. No producer was required to grow exclusively for this food network. However, the amount of livestock they provide should match the scale of farmland they own. This has formed a favorable prerequisite for organic crop production and livestock husbandry. "A producer with whom we established cooperation at the early days told us that he planned to deliver 1000 ducks to the restaurant. I told him, 'it's impossible 'cause your rice paddy field is not big enough for so many ducks to swim. Otherwise, you are lying to us" (interview code T-02). Another example is the combination of staple food crops production and pig breeding. According to the initiators, an emphasis on the integration of crop and livestock productions embodies the very traditional belief in cultivation culture in China, which shows that "the very purpose of breeding pigs is to improve the soil fertility of the arable land owned by breeders, more than to ensure protein intake from the meat" (interview code Z-01).

As a final note, the case has demonstrated a necessity to address the social consequences for smallholder producers, which derives from modern agricultural restructuring and a shift to modern food systems. A sustainable food system that advances social justice needs to take into consideration smallholders' healthcare capital and social well-beings. The growers of this local value-based supply chain found that, after years of cooperation with the network, not only their decision making autonomy on production has been enhanced, but more importantly, their health and even social status have been improved. For example, one grower who was allergic to chemical fertilizers only found herself in a healthier condition after she shifted to use only biological fertilizers. Compared with other counterparts in his village, another producer 
has enjoyed good reputation for the cleanliness of his car because he never transported fertilizers and pesticides in his vehicle. "When a local fair took place, the elderly people in his village always preferred to take a ride with him", "with this sort of admiration and praise, he was further motivated to continue practicing traditional farming" (interview code $\mathrm{T}-03)$.

\section{Conclusion}

This study has examined a local food network which created a reciprocity mechanism between smallholder producers and consumers. Driven by concerns about nutritional adequacy and food safety, consumers were willing to provide a fair price, adopt a responsible dining behavior and learn about production stories behind their local foods. These consumption attitudes and behaviors have stimulated fair production behaviors with agro-ecological farming practices. Such legitimate and justified practices have proved to be beneficial not only to the local ago-ecological system as a whole but to producers' health and social conditions as well. In a world dominated by conventional modern food systems of commercialized supply and commodity chains, this local food network has expressed alternative values and practices of resistance to the conventional way. To conceptualize social structure of this representative case of local food systems, the study proposes to draw on the concept of the moral economy originally developed in the field of peasant studies (Scott, 1977; Thompson, 1971). According to them, moral economies arise in the traditional agriculture sector of smallholders because "producers are faced with subsistence risks that help to create social systems of mutual assistance and tolerable exploitation" (Robbins, 2012). A moral economy of foods is value-based supply chain linking geographically isolated farmers with the others of their moral economy, reconnecting consumers to their local food systems. In a re-localization process of what we would term "local cultural repertoires of foods", informal networks function as equally important, if not more so, as institutionalized networks consisting of contractual agreements and protocols of certification and traceability that are common to commercialized food supply chains. While protocols of certification and traceability could constitute conclusive proofs of the moral economy of foods, a belief in sustainable food systems would stand the moral economy itself in good stead in a time when trust and confidence in the foods labeled "organic" are diminished. The moral economy of production and consumption requires virtuously responsible initiatives embracing reciprocal relations of mutual support and recognition, and a feeling of mutual obligation and co-operation. Currently, China still needs to overcome a growing number of social and environmental challenges which have become obstacles particularly for rural development. Therefore, the findings presented in the study may have significant implications for designing policies for rural vitalization with an aim to promote transitions to more sustainable agriculture and rural livelihoods. 


\section{References}

Baker, P. and S. Friel. 2016. Food Systems Transformations, Ultraprocessed Food Markets and the Nutrition Transition in Asia, Globalization and Health, 12: 64-80.

Bina, O. and S. G. Vaz. 2011. Humans, Environment and Economies: From Vicious Relationships to Virtuous Responsibility, Ecological Economics, 72: 170-178.

Chen, R. S. 1990. Global Agriculture, Environment, and Hunger: Past, Present, and Future Links. Environ Impact Assess Rev, 10 (4):335-358.

Clouse, M. 1995. Farmer Net Income from Broiler Contracts. Pittsboro, NC: Rural Advancement Foundation International-USA (RAFI).

Ezcurra, E., A. Valiente-Banuet, F. O. Lores-Villela, and E. Vasquez-Dominguez. 2001. Vulnerability to Global Environmental Change in Natural Ecosystems and Rural Areas: A Question of Latitude. In Global Environmental Risk, United Nations University Press and Earthscan Publications Ltd.

FAO. 2006. Rapid Growth of Selected Asian Economies: Lessons and Implications for Agriculture and Food Security, China and India, Bangkok: RAP Publication, 2006/05.

Forum on Health, Environment and Development (FORHEAD). 2014. Food Safety in China: A Mapping of Problems, Governance and Research. See: http://webarchive.ssrc.org/cehi/PDFs/Food-Safety-in-China-Web.pdf.

Gao, L. 2003. The Conservation of Chinese Rice Biodiversity: Genetic Erosion, Ethnobotany and Prospects, Genetic Resources and Crop Evolution, 50: 17-32.

Garnett T. and A. Wilkes. 2014. Appetite for Change: Social, Economic and Environmental Transformations in China's Food System. Food Climate Research Network, University of Oxford.

Gilbert, N. 2010. Acid Soil Threatens Chinese Farms: Overuse of Fertilizers is Imperilling Food Supply. Nature, 11 February, 2010, see:

http://www.nature.com/news/2010/100211/full/news.2010.67.html.

Goodman, D., E. M. DuPuis, and M. K. Goodman. 2012. Alternative Food Networks: Knowledge, Practice and Politics. London and New York: Routledge.

King, C. A. 2008. Community Resilience and Contemporary Agri-ecological Systems: Reconnecting People and Food, and People with People. Systems Research and Behavioral Science, 25 (1):111-124.

Lawrence, G. and J. Grice. 2008. Agribusiness, Genetic Engineering and the Corporatization of Food. In A Sociology of Food \& Nutrition: The Social Appetite. Eds., Germov, J. and Williams, L. South Melbourne, Australia: Oxford University Press, pp: 78-99.

Lewontin, R. C., J-P. Berlan. 1986. Technology, Research, and the Penetration of Capital: The Case of U.S. Agriculture, Monthly Review, 38 (3): 21-34.

Mead, M. 2008. The Problem of Changing Food Habits. In Food and culture: A Reader. Eds., Counihan, C. and P. van Esterik. New York, NY.: Routledge, pp. 17-27.

Ng, N. 2015. Long-term Overuse of Fertilisers Saps China's Farmlands. South China Morning Post, 15 July, 2015, see:

http://www.scmp.com/news/china/society/article/1839188/long-term-overuse-fertiliserssaps-chinas-farmlands. 
O'Kane, G. 2012. What is the Real Cost of Our Food? Implications for the Environment, Society and Public Health Nutrition. Public Health Nutrition, 15: 268276.

Pei, S. J. 2006. Sacred Natural Site and Biodiversity Conservation. Science, 58 (6): 2931.

Robbins, P. 2012. Political Ecology: A Critical Introduction. Oxford: Blackwell.

Roos, G., L. Terragni, and H. Torjusen. 2007. The Local in the Global: Creating Ethical Relations between Producers and Consumers. Anthropology of Food, S2, see:

http://journals.openedition.org/aof/489.

Sage, C. 2012. Addressing the Faustian Bargain of the Modern Food System: Connecting Sustainable Agriculture with Sustainable Consumption. International Journal of Agricultural Sustainability, 10 (3): 204-207.

Schlosser, E. 2001. Fast Food Nation. Boston: Houghton Mifflin.

Scott, J. C. 1977. The Moral Economy of the Peasant: Rebellion and Subsistence in Southeast Asia. New Haven and London: Yale University Press.

Secretariat of the Convention on Biological Diversity. 2014. Global Biodiversity Outlook 4. Montréal, Quebec, Canada.

Si, Z., T. Schumilas, and S. Scott. 2015. Characterizing Alternative Food Networks in China. Agriculture and Human Values, 32 (2): 299-313.

Thompson, E. P. 1971. The Moral Economy of the English Crowd in the Eighteenth Century. Past and Present, 50 (1): 76-136.

Tisdell, C. A., 2003. Socioeconomic Causes of Loss of Animal Genetic Diversity: Analysis and Assessment. Ecological Economics, 45: 365-376.

Tisdell, C. A., 2011. Biodiversity Conservation, Loss of Natural Capital and Interest Rates, Ecological Economics, 70: 2511-2515.

Turner, B. and C. Hope. 2014. Ecological Connections: Reimagining the Role of Farmers' Markets. Rural Society, 23: 175-187.

Van der Ploeg, J. D. 2010. The Food Crisis, Industrialized Farming and the Imperial Regime, Journal of Agrarian Change, 10 (1): 98-106.

Welsh, R. 1997. Vertical Coordination, Producer Rescponse, and the Locus of Control over Agricultural Production Decisions, Rural Sociology, 62 (4): 491-507.

Whatmore, S., P. Stassart, and H. Renting. 2003. What's Alternative about Alternative Food Networks? Environment and Planning A, 35: 389-391.

Xue, D., J. Wu, X. Liu, B. Lu, and S. Pei. 2015. Biodiversity Inventory and Researches. In Contemporary Ecology Research in China. Ed., Li W. Beijing: Springer and Higher Education Press, pp: 3-28.

Yu, J., J. Mo, and Q. Gong. 2016. Will Higher Industry Concentration Promote Food Safety? China Economist, 11 (2): 25-38. 